\title{
Pre-and Post-COVID-19 condition, performance and future of the airline industry: Evidence from accounting data
}

\section{Condición previa y posterior al COVID-19, desempeño y futuro de la industria de las aerolíneas: evidencia de datos contables}

Received: November 1, 2020

\begin{abstract}
The main purpose of this study was to analyze the pre-and post-COVID-19 condition, performance and future of the airline industry. To get the desired objective of the study current research study used the accounting information of airline industry. For the said purpose cross tabulation, frequencies, means techniques were used to draw the conclusion. To predict the future and revival of the industry study calculated the means before and after COVID-19 performance and forecast the recovery period of the industry. The accounting results showed that the condition and performance of the airline industry was good before the COVID-19 pandemic. The average results showed that operating profit margin, net profit, return on invested capital and, revenues were at acceptable levels before COVID-19. However, in the aftermath of COVID-19, all the indicators dropped significantly and become negative. Before COVID-19, the airline industry was contributing an average $\$ 118$ billion in annual tax revenue to governments. Before COVID-19, the region-wise accounting results showed that the condition and performance of the airline industry was good in all regions except in Africa. After COVID-19, the airline industry in all regions encountered significant problems with negative operating profit, net profit and, return on invested capital, and a significant drop in revenue. In short, such unexpected, painful and huge losses have never been recorded throughout the history of the airline industry. The future of the airline industry is unpredictable and uncertain, but the average results showed that said industry will recover within four to five years if COVID-19 disappears in 2020.
\end{abstract}

Accepted: December 21, 2020

\author{
Written by: \\ Qaiser Aman 1 \\ https://orcid.org/0000-0003-4358-7940 \\ Sultan Altass ${ }^{2}$ \\ https://orcid.org/0000-0003-3733-7400
}

\section{Resumen}

El objetivo principal de este estudio fue analizar la condición, el desempeño y el futuro de la industria de las aerolíneas antes y después del COVID-19. Para obtener el objetivo deseado del estudio, el estudio de investigación actual utilizó la información contable de la industria aérea. Para dicho propósito, se utilizaron técnicas de tabulación cruzada, frecuencias y medias para sacar la conclusión. Para predecir el futuro y la reactivación de la industria, el estudio calculó las medias antes y después del desempeño de COVID19 y pronosticó el período de recuperación de la industria. Los resultados contables mostraron que la condición y el desempeño de la industria de las aerolíneas eran buenos antes de la pandemia de COVID-19. Los resultados promedio mostraron que el margen de utilidad operativa, la utilidad neta, el rendimiento del capital invertido y los ingresos se encontraban en niveles aceptables antes de COVID-19. Sin embargo, a raíz de COVID-19, todos los indicadores cayeron significativamente y se tornaron negativos. Antes de COVID-19, la industria de las aerolíneas contribuía con un promedio de \$ 118 mil millones en ingresos fiscales anuales a los gobiernos. Antes de COVID19, los resultados contables regionales mostraban que la condición y el desempeño de la industria de las aerolíneas eran buenos en todas las regiones excepto en África. Después de COVID-19, la industria de las aerolíneas en todas las regiones enfrentó problemas significativos con ganancias operativas negativas, ganancias netas y retorno del capital invertido, y una caída significativa en los ingresos. En resumen, pérdidas tan inesperadas, dolorosas y enormes nunca se han registrado en la historia de la industria de las aerolíneas. El futuro

\footnotetext{
${ }^{1}$ Ph. D, Associate Professor, Department of Accounting, College of Business, King Abdulziz University Jeddah, Rabigh Campus.

${ }^{2} \mathrm{Ph}$. D, Head of Accounting Department, College of Business, King Abdulaziz University Jeddah, Rabigh Campus.
} 
Keywords: Accounting performance, Airline industry, COVID-19, Return on invested capital and Net Profit.

\section{Introduction}

In the modern era accounting information has become indispensable for businesses and many other stakeholders. As a business grows, it requires full-time attention to a variety of business-related details and market-related issues. Without proper accounting information, no business can achieve its desired goals. The ultimate goal of a business is to maximize its profit. To ensure it makes a profit, a business needs to make better decisions and better decisions need accurate, reliable, verified and timely accounting information. Currently, we are living in a dynamic environment with a significant amount of healthy competition. To gain a competitive edge companies need up-todate accounting information. No organization has unlimited resources. Thus, organizations must use their limited resources in a proper way. That is why they are taking smart steps to utilize their resources efficiently and effectively. In this regard, use an accounting information system to facilitate their decisions-making process and provide financial data to various users, such as an accountants, consultants, financial advisors, managers, auditors, government tax agencies and investors.

Various accounting information systems consider operating tool such as cash, revenue, inventory, account receivables, account payables, profit before tax, and profit after tax, investment, and return on investment, operating expenses, dividends and taxes. These accounting information systems needs proper policies, which are an integral part of companies. Companies formulate policies to address their present and future needs, policies reflect the vision of the companies, and without vision there is no future, especially in an era such as the current one. The present business scenario is complex, and technology is the main driver behind it. Businesses should be up-to-date on all business-related aspects, such as the present market, the future market, their customers' attitudes, aptitudes, perceptions, value, buying power, buying habits and needs, government policies, market trends, market shocks, events, customers' reactions, competitors' strategies, de la industria de las aerolíneas es impredecible e incierto, pero los resultados promedio mostraron que dicha industria se recuperará dentro de cuatro a cinco años si COVID-19 desaparece en 2020.

Palabras clave: Desempeño contable, Industria aeronáutica, COVID-19, Retorno del capital invertido y Utilidad neta.

global trends, natural and political disasters, interest rates, economic factors, political factors, social factors, technological factors and the companies' strengths, weaknesses, opportunities and threats. Companies that address these factors and spend money based on the sensitivity of these become successful.

A business's performance is the ultimate indicator of its success. A good performance gives a company competitive advantage. These companies can expand their business; they can effective manage the controllable and noncontrollable factors. Business Performance can be measured using financial and non-financial factors. Financial performance can be measured through traditional accounting performance measures such as net profit (NP), return on capital, return on investment and return on sales. Non-financial performance can be measured through, customer satisfaction, employee turnover, employees' turnover intentions, and employee satisfaction.

\section{Airline Industry and Major Events in the World}

The transportation industry provides services to people when they want to travel from one place to another. It also supports businesses by providing cargo services to move goods. The transportation sector is comprised of several industries including air freight and logistics, airlines, marine, road and rail and transportation infrastructure. Hayes (2020).

The transportation sector plays a vital role in the development of businesses and economies. Nothing is possible without it. Before COVID19 , its importance not often highlighted. The airline industry is one of the major transportation sectors in the world. It also is one of the primary industries that supports the globalization. It transports goods, people, and technology from country to country very quickly. It facilitates international trade and tourism, and it has transformed the world into a global village. 
Without the airline industry, globalization would remain a dream.

The air transport industry provides services to people (passengers) and businesses (cargo). These air transport services have encouraged businesspeople to establish various businesses such as hospitality, tourism, import and export businesses, online shopping. The airlines industry also offers a variety of careers such as pilots, flight attendants and ground crews.

Across the globe the air transport industry is divided into six regions: Africa, Asia Pacific, Latin America, North America, the Middle East and Europe. In 1945, only 57 airlines were registered with the International Air Transport Association (IATA). In 2020, 296 airlines are registered with IATA. This indicates sufficient improvement in the air transport business. In 2019, the airline industry also facilitated the ability for businesses to engage in commercial activity worldwide. It supported approximately 64 million tonnes of cargo globally. This increased the worth of world trade by one-third, created 65 million jobs and generated \$2.7 trillion in gross domestic product (GDP), worldwide. (http://www.iata.org).

Air transport is a highly seasonal and very sensitive industry. In some years, the air transport industry is negative impacted by a "black swan" event or a commercial recession. Many events can have a harmful effect on the airline industry, including stagnation in the 1990s, the Gulf War the dot-com bust and the 9/11. After 9/11 attacks in the United States (US). After 9/11, the demand for air travel decreased by more than $30 \%$ in the US. This shock significantly decreased the capacity and impacted more than 62,000 commercial airline employees; at that time, the airline industry represented $11 \%$ of the total rate of employment in the US economy.

After 9/11, there was slight upturn, but severe acute respiratory syndrome (SARS) outbreak significantly affected East Asia and Canada between November 2002 and July 2003. Some years later, H5N1 avian influenza impacted Southeast Asia. In 2008, the global financial crisis significantly affected the world's economy as well as the health of the airline industry. In the same year, the H1N1 swine flu pandemic affected North America, and the eruption of the
Eyjafjallajökull volcano in Iceland spewed ash into European airspace. After a number of stable years, the avian flu returned in 2013, but then Ebola, MERS and Zika threatened the global community and impacted economies around the world. Regardless of these recessions, airline traffic has shown stable long-term growth since the 1970s. Sehl, K (2020).

In December 2019, novel COVID-19 was discovered in the city of Wuhan in China. Initially, it was seen as an epidemic in China, but within months the virus quickly spread around the globe and the World Health Organization (WHO) acknowledged COVID-19 as a pandemic in March 2019. According to medical scientists epidemic is an extensive occurrence of a disease in excess of what might normally be expected to occur in a geographical region. A pandemic is an outbreaks diseases across international borders https://www.mphonline.org/worst-pandemicsin-history/. That is why WHO considered COVID-19 to be a pandemic and launched a separate link on its web site. WHO has given full attention to COVID-19; every day it posts undated information on the number of COVID19 patients by country. COVID-19 has had a greater impact than other pandemics. In April 2020, more than 140 airlines reduced their volume to $10 \%$ or less. Thus the shutdown related to COVID-19 has also increased the industry's need to retire some of its aircraft fleet. Lufthansa plans to permanently ground 32 aircraft, retiring six Airbus A380s, seven longhaul A340-600s and five Boeing 747-400s ahead of schedule. German wings, which operated under the low-cost Euro wings brand with 33 aircraft, ceased operations. Austrian Airlines plans to downsize its fleet from 80 to 60 aircraft by 2022 . British Airways announced that it is up to 12000 employees due to COVID-19.

Almost all sectors of the world's economy have been affected by COVID-19. Many countries have announced lockdowns and have closed their international borders, which has had a negative impact. Some companies have shut down operations and announced that they are downsizing; ultimately, this leads to increased unemployment worldwide. Some companies have solvency and liquidity problems. In short, COVID-19 has created many problems for the world's economies, and its impact will remain long after the virus is under control. 
Air Passenger Traffic and Pandemic

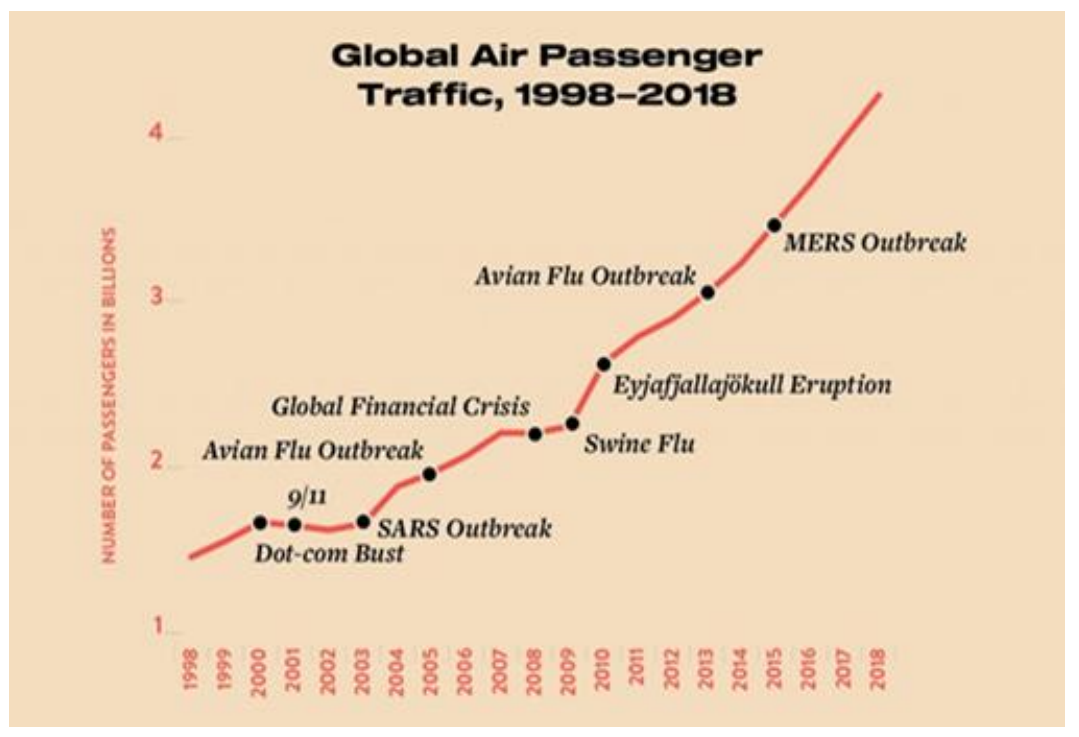

Sources: World Bank and International Civil Aviation Organization.

The graph is presented above shows that global air passenger traffic from 1998 to 2018 was negatively impacted by various pandemics and epidemics around the world.

\section{Objective of the study}

The main objective of the study was to examine the pre- and post- COVID-19 condition, performance and future of the airline industry.

\section{Literature Review}

Various studies have investigated the interaction between pandemic and economic dynamics and they have reported different results. The unspecified timeline for eliminating social distancing and travel limitations related to COVID-19 has increased doubt for the air transport industry. The US administration has approved a large incentive bill to support stricken industry (Gilbertson, 2020). Regardless of this incentive to help the distressed air transport.

Eichenbaum et al. (2020) examined the interaction between epidemics and economic sensitivities using theoretical modelling. They proposed that restraint policies that encourage decreases in consumption and work can significantly decrease the number of death during a pandemic. Unfortunately, these guidelines adversely impact the economy and ultimately result in a later downturn. Barro et al. (2020) studied the Spanish flu and the WWI death rates as proxies to measure the fiscal impact that might be imposed on a country throughout a pandemic. Their examination estimated that, on average a nation will experience a $6 \%$ drop in intake and an $8 \%$ drop GDP. As a result of COVID-19, the predictable drop in intake is being understood as unemployed rights grasp approximately 10 million in March 2020 (Wolfers, 2020).

Sobieralski, (2020) examined the effects of uncertainty shocks by COVID-19 on the workforce of the US airline. He found that the entire US airline workforce will decrease from $7 \%$ to $13 \%$. Employees of leading airlines are most impacted by the shock followed by employees at low-cost airlines and then those at regional airlines. The unskillful airline workforce faces a major threat during these labour force reductions. In the airline industry leading carriers have experienced a capacity shrinkage of approximately 60-80\%.

According to Barro et al. (2020), an enlarged capital market and interest rate unpredictability occur during pandemics. Their findings suggest that situations similar to the present COVID-19 pandemic can have an impact on financial situations that would be as grave as the Great Recession. Atkeson (2020) used models to forecast the extent of COVID-19 and reported that social distancing and the related economic adjustments could last for approximately 18 months. Moreover, McKibbin and Fernando (2020) used data from China to model the potential impacts from the COVID-19 outbreak. They found uneven assessments of a $1 \%-5 \%$ 
shock to consumption, a capital risk gain jolt of $1.07 \%-1.33 \%$, and a workforce source shock of up to $1.4 \%$. The real fiscal and social impacts from the COVID-19 pandemic are still emerging; however, the ambiguity of the pandemic is obvious and increasing as states make an effort to address and alleviate the spread of the virus. Improbability has been found to be a significant driver in several stagnations and doubt-linked commercial surprises can spread over periods of time (Caggiano et al., 2014).

Basu and Bundick, (2017) reported that uncertainty jolts can be affected by several factors, such as financial crunches, terror-related actions, disease outbreaks and natural disasters. The rise and fall in ambiguity generate a misleading opinion for individuals, industries, and commercial managers. An experiential economic investigation has considered the subject of doubt jolts with respect to larger economic situations. An upsurge in doubt tends to negatively affect actual economic activity.

Aman \& Altass (2019) investigated the capital structure and firm performance of Emirates airline. They found mixed results. Debt to assets finds no significant relation with return on assets. Results showed that there is no significant relation debt to assets with return on equity. Whereas debt to assets have relation with net profit margin. It is worth mentioning that due COVID-19 pandemic it is very difficult for the management to raise capital through debt or equity. Overall performance of the airline industry in down turn and airline industry can't attract the investors.

Ludvigson et al. (2015) found that the shrinkage in actual macroeconomic actions is initiated by defensive investments by individuals and companies as well as the succeeding work losses. The Great Recession was driven by economic insecurity in the market. This uncertainty overshadowed policymakers' actions given the constraints imposed by a federal funds rate near 0\% (Caggiano et al., 2017). The existing state of the economy is also noted as a determinant of the responsiveness of players to uncertainty (Alessandri and Mumtaz, 2019). Two factors are responsible for uncertainty shocks: globalization and GDP growth (Bloom, 2014). Globalization has created an interlinked system and economies that are connected by the vigorous network of air transportation (Mahutga et al., 2010, Aman, \& Altass, 2019, Legchilina, 2020).
According to Davies (2016), the air transport industry has been vulnerable due to worldwide disasters throughout history, including constraints of oil, airline deregulation, and terrorist attacks. Franke and John (2011) reported that the 9/11 attacks in the US resulted in a substantial decrease in passenger traffic and the air transport industry resisted to continue operations. After $9 / 11$ the spread of SARS in 2004 reduced demand for air travel to levels seen before 2001. Tan (2016) reported that low-rate carriers increased their market share because the main air carriers resisted making improvement due to the pricing war that occurred during 9/11 and SARS.

Legchilina (2020) analyzed the impact of changes in labor relations on mortality rate in Russia. He found that there is negative and significant relation with mortality rate and work life quality. Working condition impact on the mortality rate dynamics. He also found that mortality rate also the effect the labor relations. Sibdari et al. (2018) found that increasing oil rates was also a problem impeding the ability the rescue the air transport industry following 2001. The main airlines adjusted their capacity to offset the increased cost, leaving lower priced carriers the opportunity to drive in new markets. Pearce (2012) investigated the Great Recession and its impact on the air transport industry. He noted that carriers changed their routing and network arrangements to alleviate the effects of the decrease in demand caused by reduction in their capacity.

Von Nordenflycht and Gittell (2013) reported that very few studies examined the variations in the airlines' labor force due to these economic shocks. In 9/11, many carriers reorganized their operations to reduce their variable and fixed costs. They studied the bankruptcies and mergers that occurred during pandemic and epidemic periods in which airlines adopted workforce reductions and renegotiated labour contracts. Workforce reductions had a significant impact on employees. Some airlines announced cuts in wages and benefits, which ranged from $9 \%$ to $50 \%$ depending on the type of job.

Goodman, (2008) found that downsizing was not meant to be a long-term strategy; the airlines started bargaining with their workers by negotiating labour agreements. While the demand for airline industry services was improving, the industry was still overwhelmed by persistent employment loss. 
In short, the air transport industry has absorbed many shocks and has returned to normal levels after those shocks. It is forecasted that the air transport industry travel demand will resumed to pre-recession levels within 18 months. Eventually, the COVID-19 will be under control.

\section{Research Methodology}

The study aimed to determine the health, condition, performance and future (HCGP\&F) of the air transport industry, per-and post-COVID19. For that purpose, this research to identified a financial assessment framework that could help various users, such as investors, a company's management, government, consumers, suppliers and regulators. The results of this research offer a recommended framework that the air transport industry could use to gauge its financial health, condition, performance and future. The framework includes a ratio analysis using selected ratios compiled by this study. This study also forecasted the health of the airline industry post- COVID-19 and found that its capacity level would return to normal during a post-COVID-19 recovery period.

This research utilized a four-phase approach. In the first phase, literature review was conducted focusing on studies on the pandemic/epidemic and the airline industry. In second phase, data on selected variables were collected. I the third phase, data were analyzed to measure the health, condition, performance and future of the airline industry. In the fourth-phase, the findings were reported and conclusion were drawn. The financial assessment framework incorporates factors like, operating profit margin (OPM), net profit margin (NPM), return on invested capital (ROIC), revenues trend and aircraft fleet and, tax contributions in relation to business performance.

Earnings before interest and taxes (EBIT) is also known as operating income/profit. It is a very important indicator for assessing the performance of a business. A business deducts all the operating expenses from its revenues and determines whether or not the earnings are sufficient to meet its other needs. The following equation is used to calculate the OPM:

$$
O P M=E B I T-/-R E V E N U E
$$

NPM is another indicator that is used to assess the health of a business. This information is used to stimulate business and attract investor. A business also uses this factor to gain a competitive edge over its competitors. Sufficient
NPM is good for the business, its employees, its investors, and its creditors as well as for the government. Its formula is as follows:

NPM= Net Income $/$ Revenue

Revenue is the income earned by a business over a specific period, such as month, quarter or year. Revenues seem to be a good performance indicator of a business. If revenues are increasing, a business is doing well, and vice versa. Al most every business wants to enhance its revenue and will spend millions of dollars on marketing to achieve that goal. The amount of Revenue depends upon on the quality of services, fares, facilities and brand image. Two costs are very important: such as fixed costs and variable costs. These costs determine the breakeven point of a business. Businesses calculate the breakeven point for profit planning. The airlines industry earns revenues from sales of passenger tickets and freight charges from cargo. The airlines industry's revenues can be calculate as follows:

Revenues $=$ Fare $*$ No. of tickets sold $\quad$ (III) Revenues $=$ Freight charges

ROIC is the ultimate goal of a business. Every business wants to maximise ROIC as much as possible. To do so, a business needs good investment opportunities with reliable information and technical analysis. This factor requires a business' full attention because its current and future performance depend on it. It is well known, that no organisation has unlimited resources, so a business must secure outside assistance when needed. Capital can be raised through debt, equity and retained earnings. A sufficient ROIC can increase the trust of investors and encourage of new investors. It is also a good indicator of a business' current and future health. It is measured using the following formula:

\section{Return on invested capital $=$ Net profit/- Total capital \\ (IV)}

The industry's tax contribution will also be considered pre-and post-COVID-19.

This research also measured the impact of the COVID-19 pandemic on the airline workforce. Assessing the airline industry's employment contribution will also determine how much employment opportunities the industry creates, which also has impact on the economies of the world. Aircraft fleet investment is another important factor to consider. It represents the growth in the airline industry. This factor is also 
important for aircraft in term of the demand, supply and growth of aircraft manufacturing companies. The Current study also measures the pre-and post-COVID-19 impact on the size of the airline aircraft fleet. It is worth mentioning that trade is an integral part of the world economy. Trade is one of the most important factors of globalization. All activities depend upon it. Due to trade, some countries are developed, others are less developed and others, are still developing.

This research also investigated how COVID-19 has impacted the value of trade that is supported by the airline industry.

\section{Data Presentation and Analysis}

This study used secondary data obtained from the IATA. The study used descriptive analysis to measure the impact of COVID-19 on the airline industry and to draw its conclusions.

\section{Ratio Analysis}

Ratio analysis is a tool that actually reduces the large figures and presents them an understandable format. It is a good approach to analyse accounting information and measure the performance, condition, health and future of a business. This study used accounting information and selected ratios to evaluate the performance, condition, health and future of the airline industry. Following accounting information used is this study and the results of the selected ratio are presented in Table 1.

Table 1.

Selected Ratios of the Airline Industry.

\begin{tabular}{|c|c|c|c|c|c|c|c|c|c|c|c|c|c|c|c|c|c|}
\hline Years & 2004 & 2005 & 2006 & 2007 & 2008 & 2009 & 2010 & 2011 & 2012 & 2013 & 2014 & 2015 & 2016 & 2017 & 2018 & 2019 & $2020 \mathrm{~F}$ \\
\hline Operating & & & & & & & & & & & & & & & & & \\
\hline $\begin{array}{l}\text { Profit(\$ } \\
\text { billion) }\end{array}$ & 3.3 & 4.4 & 15 & 19.9 & -1.1 & 1.9 & 27.6 & 19.8 & 18.4 & 25.3 & 35.5 & 62 & 60.1 & 56.6 & 45.9 & 43.2 & -98 \\
\hline EBIT & 0.9 & 1.1 & 3.2 & 3.9 & -0.2 & 0.4 & 4.9 & 3.1 & 2.6 & 3.5 & 4.6 & 8.6 & 8.5 & 7.5 & 5.7 & 5.2 & -23.4 \\
\hline $\begin{array}{l}\text { Net Profit,(\$ } \\
\text { billion) }\end{array}$ & -5.6 & -4.1 & 5 & 14.7 & -26 & -4.6 & 17.3 & 8.3 & 9.2 & 10.7 & 13.8 & 36 & 34.2 & 37.6 & 27.3 & 26.4 & -84 \\
\hline $\begin{array}{l}\text { \% Margin } \\
\text { Per }\end{array}$ & -1.5 & -1 & 1.1 & 2.9 & -4.6 & -1 & 3.1 & 1.3 & 1.3 & 1.5 & 1.8 & 5 & 4.8 & 5 & 3.4 & 3.1 & -20 \\
\hline $\begin{array}{l}\text { Departing } \\
\text { Passenger, (\$) } \\
\text { Return on }\end{array}$ & -2.8 & -1.9 & 2.2 & 6 & -11 & -1.9 & 6.4 & 2.9 & 3.1 & 3.4 & 4.2 & 10.1 & 9 & 9.2 & 6.2 & 5.8 & -38 \\
\hline $\begin{array}{l}\text { Invested } \\
\text { Capital (\%) }\end{array}$ & 3.3 & 3.3 & 4.7 & 5.7 & 1.3 & 1.9 & 6.2 & 4.7 & 4.6 & 4.8 & 5.9 & 7.9 & 7.2 & 6.8 & 6.5 & 5.8 & -17 \\
\hline
\end{tabular}

Source: iata.org

Table 1 shows the results of operating profit, EBIT, NP, NPM, per departing passenger and ROIC from 2004 to 2020. The results indicate that, after SARS (2003) pandemic there was significant improvement in the airline industry's operating profit. A very sharp decline in operating profit occur during the 2008 global financial crisis and its impact continued until 2009. After these two jolts (SARS and the global financial crisis) the airline industry started to rebound, but COVID-19 had a negative impact on the operating profit in 2020, which sharply declined. Similarly, EBIT, NP, NPM and ROIC were affected by SARS and the global financial crisis, but the impact on these due to COVID-19 unprecedented. COVID-19 has significantly affected the airline industry and whole industry which is facing significant challenges in terms of its survival, return to investors, compensations to employees, etc. While the ROIC is sufficient throughout the sample period, the results show that ROIC decrease during the global financial crisis. After that time period, the ROIC was substantial but COVID-19 has severely affected the returns; ROIC, has declined and come to $17 \%$, which is unprecedented throughout the history of the airline industry. Investors enjoyed sufficient returns before COVID-19. 
Table 2.

Selected Ratios Pre-and Post-COVID-19 Impact.

\begin{tabular}{lllll}
\hline Variables & Pre COVID-19 & Post COVID-19 & Impact & Recovery Period \\
\hline Operating & 27.3625 & -98 & -70.6375 & -2.58 \\
Profit (\$ billion) & 3.96875 & -23.4 & -19.4313 & -4.90 \\
\% Margin & 12.50625 & -84.3 & -71.7938 & -5.74 \\
Net Profit & 1.6375 & -20.1 & -18.4625 & -11.27 \\
(\$ billion) & 3.2125 & -37.5 & -34.2875 & -10.67 \\
\% Margin & 5.0375 & -16.9 & -11.8625 & -2.35 \\
Per Departing Passenger (\$) & & & \\
Return on Invested Capital $(\%)$ & &
\end{tabular}

Source: Data calculated by researchers (2020)

The study calculated the average operating profit, EBIT, NP, NPM per departing passenger and ROIC Pre-COVID-19 from 2004 to 2019 and compared the resultS with post WITH THE postCOVID-19 values. As seen in Table 2 per-and post-COVID-19 differences were divided by the pre-COVID-19 average results. The results show that all the variables were negatively impacted by COVID-19 and the difference between the preand post-COVID-19 impact is very high. Thus, it was concluded that the airline industry will return to its average operating profit within 2.58 years, and the EBIT comeback will be positive within
4.90 years. However, it will take 5.74 years for NP to come back to its average before COVID19. Similarly, per departing passenger and return on ROIC will recover within 10.67 years and 2.35 years, respectively.

\section{Regional Performance of the Airline Industry}

The airline industry is divided into six regions across the globe. The region-wise accounting information and business performance of this industry is presented in Table 3.

Table 3.

Region-wise EBIT.

\begin{tabular}{llllllllllll}
\hline Regions & 2010 & 2011 & 2012 & 2013 & 2014 & 2015 & 2016 & 2017 & 2018 & $2019 \mathrm{~A}$ & $2020 \mathrm{~F}$ \\
\hline Global & 4.9 & 3.1 & 2.6 & 3.5 & 4.60 & 8.60 & 8.50 & 7.50 & 5.70 & 5.20 & -23.40 \\
North America & 5.7 & 3 & 3.4 & 6.8 & 9.10 & 14.40 & 13.70 & 11.20 & 9.10 & 9.60 & -21.20 \\
Europe & 2.4 & 0.8 & 0.7 & 2 & 3.10 & 5.50 & 6.10 & 7.90 & 6.20 & 4.80 & -21.60 \\
Asia-Pacific & 8 & 6.6 & 4.7 & 2.9 & 2.40 & 6.90 & 7.40 & 6.30 & 4.70 & 3.70 & -27.50 \\
Middle East & 3.7 & 3.1 & 3 & 0.9 & 3.00 & 6.30 & 2.20 & -3.00 & -4.60 & -5.20 & -21.00 \\
Latin America & 5.1 & 2 & 1.5 & 2.2 & 5.00 & 5.00 & 5.60 & 6.20 & 2.70 & 2.90 & -21.70 \\
Africa & 1.7 & 0.6 & -0.4 & -0.5 & -2.70 & -2.10 & 1.10 & 0.80 & 1.50 & 1.00 & -29.00 \\
\hline
\end{tabular}

Source: iata.org (Economics Reports 2015 and 2020)

EBIT is a good predicator of the operating performance of a business. The results presented in Table 3 show that, overall the EBIT of the airline industry was positive from 2010 to 2019, but it has a mixed trend throughout the period. COVID-19 had a negative impact on the EBIT of the airline industry; it was -23.40 , which is the lowest it has been in the history of the airline history. North America, Europe and Asia-Pacific had a positive EBIT from 2010 to 2019, in all the years with increasing and decreasing trends but COVID-19 had an adverse impact on EBIT $(-21.20,-21.60$ and -27.50 , respectively). While the Middle East and Africa also had a negative EBIT for some of the years before COVID-19, the pandemic increased negative impact on this factor. Latin America had stable EBIT for some years and an increase and decrease in other years. COVID-19 also affected the Latin America with an EBIT of -21.70 . 
Table 4.

Pre-and Post-COVID-19 Impact on Region-wise EBIT.

\begin{tabular}{lllll}
\hline Regions & Pre-COVID-19 & Post COVID-19 & Impact & Recovery Period \\
\hline Global & 5.42 & -23.40 & -17.98 & -3.32 \\
North America & 8.6 & -21.20 & -12.60 & -1.47 \\
Europe & 3.95 & -21.60 & -17.65 & -4.47 \\
Asia-Pacific & 5.36 & -27.50 & -22.14 & -4.13 \\
Middle East & 0.94 & -21.00 & -20.06 & -21.34 \\
Latin America & 3.82 & -21.70 & -17.88 & -4.68 \\
Africa & 0.1 & -29.00 & -28.90 & -289.00 \\
\hline
\end{tabular}

Source: Data calculated by the researchers (2020)

In North America, the airline industry was doing well before COVID-19 in comparison to all the other regions, followed by Asia-Pacific, Europe, Latin America and Africa. In North America, the industry will absorb the impact of COVID-19 very quickly and it will recover the EBIT within 1.47 years. It will take the Asia-Pacific, European and Latin America regions 4.13 years, -4.47 and -4.68 years respectively, return to the average EBIT they experienced pre-COVID-19. The Middle East and African regions will remain problematic for many years. The impact of COVID-19 will be prolonged and these two regions (Middle East and Africa) will need some extraordinary efforts to revive their airline industry, otherwise their survival will remain at stake.

Table 5.

Region-wise Net Profit (\$ Billion)

\begin{tabular}{llllllllllll}
\hline Years & 2010 & 2011 & 2012 & 2013 & 2014 & 2015 & 2016 & 2017 & 2018 & 2019 & $2020 \mathrm{~F}$ \\
\hline Global & 17.3 & 8.3 & 6.1 & 10.6 & 13.8 & 36 & 34.2 & 37.6 & 27.3 & 26.4 & -84.3 \\
Regions & & & & & & & & & & & \\
North America & 4.2 & 1.7 & 2.3 & 7.4 & 11.1 & 21.7 & 17 & 17.8 & 14.5 & 17.4 & -23.1 \\
Europe & 1.9 & 0.3 & 0.4 & 1 & 1.9 & 7.1 & 8.5 & 8.9 & 9.1 & 6.5 & -21.5 \\
Asia-Pacific & 9.2 & 5 & 2.7 & 1.9 & 0.5 & 7.5 & 7.4 & 10.5 & 6.1 & 4.9 & -29 \\
Middle East & 0.9 & 1 & 1 & 0.3 & 1.1 & 2.1 & 1.3 & 0.1 & -1.5 & -1.5 & -4.8 \\
Latin America & 1 & 0.2 & -0.2 & 0.2 & 0.1 & -1.6 & 0.4 & 0.5 & -0.8 & -0.7 & -4 \\
Africa & 0.1 & 0 & -0.1 & -0.1 & -0.9 & -0.8 & -0.4 & -0.2 & -0.1 & -0.3 & 0.2 \\
\hline
\end{tabular}

Source: iata.org (Economic Reports 2015 and 2020)

NP is the ultimate target of a business and every business wants to double its NP every year. Overall, the airline industry was enjoying a good NP before COVID-19, but COVID-19 had a severely negative impact on NP (\$-84.3 billion). North America, Europe and Asia-Pacific were doing well before COVID-19. However, since COVID-19 the NP of the airline industries in these regions decreased and airlines are bearing significant losses in comparison to their preCOVID-19. The NP for the Middle East, Latin America and Africa regions was not as good as the NP for the North America, Europe and AsiaPacific regions because these regions experienced losses in some of the years prior to the COVID-19 pandemic.

Table 6.

Pre-and Post-COVID-19 Impact on Region-wise Net Profit.

\begin{tabular}{lllll}
\hline Regions & Pre COVID-19 & Post COVID-19 & Impact & Recovery Period \\
\hline Global & 21.76 & -84.3 & -62.54 & -2.87 \\
North America & 11.51 & -23.1 & -11.59 & -1.01 \\
Europe & 4.56 & -21.5 & -16.94 & -3.71 \\
Asia-Pacific & 5.57 & -29 & -23.43 & -4.21 \\
Middle East & 0.48 & -4.8 & -4.32 & -9.00 \\
Latin America & -0.09 & -4 & -4.09 & 45.44 \\
Africa & -0.28 & 0.2 & -0.08 & 0.29 \\
\hline
\end{tabular}

Source: Data calculated by researchers (2020) 
The average NP of the airline industry preCOVID-19 was $\$ 21.76$ billion. Post-COVID-19, the NP was negative (i.e. $\$-84.3$ billion). It is calculated that the airline industry will rebound within 2.87 years and will earn an average NP in 2023. In North America, the difference in the impact is \$-11.59 and the industry in that region will recover after 1.01 years and earn an average NP in 2022. Europe and Asia-Pacific will earn NP in 2023 and 2024, respectively. In Latin America, the industry will take many years to recover its NP. This region must make extraordinary decisions for the survival of its airline industry. In Africa, NP will recover very quickly because its loss and profit were low per-
COVID-19, which is why the COVID-19 impact is low.

\section{Traffic Results}

The total number of travel reservation controlled by the worldwide airline industry has increased. Slated passengers refer to the number of passengers that have booked a flight with a commercial airline; charter flights are excluded. As of 2018, the Asia Pacific region had the highest share of airline passenger traffic accounting for around one-third of the global total. The region also includes the busiest air routes_Mazareanu, E (2020).

Table 7.

Passenger Traffic (RPK) \% change over Year.

\begin{tabular}{llllllllllll}
\hline Regions & 2010 & 2011 & 2012 & 2013 & 2014 & 2015 & 2016 & 2017 & 2018 & 2019 & $2020 \mathrm{~F}$ \\
\hline Global & 8 & 6.3 & 5.3 & 5.7 & 6 & 7.4 & 7.4 & 8.1 & 7.4 & 4.2 & -54.7 \\
North America & 4.5 & 2.9 & 1 & 2.3 & 3 & 4.5 & 4.3 & 4 & 5.3 & 3.9 & -52.6 \\
Europe & 4.3 & 8.4 & 4.6 & 3.9 & 6.5 & 5.8 & 5.3 & 9.1 & 7.5 & 4.3 & -56.4 \\
Asia-Pacific & 11.8 & 6.6 & 6.1 & 7.2 & 7.8 & 9.6 & 11.1 & 10.8 & 9.3 & 4.8 & -53.8 \\
Middle East & 17.6 & 10 & 14.7 & 11.6 & 11.9 & 9.9 & 11.4 & 6.8 & 5 & 2.3 & -56.1 \\
Latin America & 12.4 & 11.3 & 9.4 & 6.3 & 6.4 & 6.7 & 4.5 & 7.3 & 7.4 & 4.1 & -57.4 \\
Africa & 12.3 & 1.6 & 7.5 & 4.6 & 0.6 & 3.4 & 7.3 & 5.5 & 6.1 & 4.5 & -58.5 \\
\hline
\end{tabular}

Source: iata.org (economics Reports2015 and 2020)

Table 7 shows the changes in the revenue passenger kilometres (RPKs) from 2010 to 2020. It can be seen that there is remarkable change

year after year, which is good for the airline industry. All the regions were doing well preCOVID-19. Due to COVID-19 most of the countries announced lockdowns and movement restrictions. These restrictions and lockdowns adversely affected the RPKs in all of the regions. Africa is the region in which the RPKs were most affected, followed by Latin America then the Middle East, Europe, Asia-Pacific and North America.

Table 8.

Pre-and Post-COVID-19 Impact on Passenger Traffic (RPKs) \% Change by Year.

\begin{tabular}{llll}
\hline Regions & Pre COVID-19 & Post COVID-19 & Impact \\
\hline Global & 6.58 & -54.7 & -48.12 \\
North America & 3.57 & -52.6 & -49.03 \\
Europe & 5.97 & -56.4 & -50.43 \\
Asia-Pacific & 8.51 & -53.8 & -45.29 \\
Middle East & 10.12 & -56.1 & -45.98 \\
Latin America & 7.58 & -57.4 & -49.82 \\
Africa & 5.34 & -58.5 & -53.16 \\
\hline
\end{tabular}

Source: Data calculated by the researchers (2020)

Significant differences in the average RPKs results pre-COVID-19 and post-COVID-19 were found in all the regions. It will take all the regions a number of years to return their RPKs normal operational levels. This natural disaster (COVID19) upset is not normal; it affected the entire industry, which is unprecedented throughout its history. 
Table 9.

Passenger Capacity (ASKs) \% Change by Year.

\begin{tabular}{llllllllllll}
\hline Year & 2010 & 2011 & 2012 & 2013 & 2014 & 2015 & 2016 & 2017 & 2018 & 2019 & $2020 \mathrm{~F}$ \\
\hline Global & 4.5 & 6.6 & 4 & 5.2 & 5.8 & 6.7 & 7.5 & 6.7 & 6.9 & 3.4 & -40.4 \\
North America & 2.3 & 2.8 & 0 & 2 & 2.8 & 4.1 & 4.7 & 3.9 & 4.9 & 2.9 & -35.2 \\
Europe & 1.7 & 8.9 & 2.6 & 2.7 & 5.8 & 4.5 & 5.3 & 6.9 & 6.5 & 3.6 & -42.9 \\
Asia-Pacific & 6.3 & 7 & 5.3 & 7.1 & 8.1 & 7.5 & 10.1 & 9 & 8.7 & 4.5 & -39.2 \\
Middle East & 13.3 & 9.8 & 12 & 12.3 & 10.9 & 12.6 & 13.2 & 6.2 & 5.8 & 0.1 & -46.1 \\
Latin America & 6.8 & 9.3 & 7.3 & 4.5 & 4.3 & 6.5 & 3.3 & 5.4 & 7.8 & 3 & -43.3 \\
Africa & 9.3 & 3.2 & 6.3 & 4 & 3.5 & 2.4 & 6.9 & 2.2 & 4.3 & 4.2 & -50.4 \\
\hline
\end{tabular}

Source: iata.org (Economics Reports 2015 and 2020)

These accounting statistics illustrate the change in available seat kilometres (ASKs) of commercial airlines worldwide from 2010 to 2020, broken down by region. In the Middle East region, the growth in ASKs is very high over the years; however, after 2016, the ASKs increased in the Asia-Pacific region. In 2019, the ASKs in the Asia-Pacific region grew by $4.5 \%$, which is high in comparison to all the other regions. ASKs were also significantly affected by COVID-19; the ASKs growth decreased in all the regions. The highest passenger capacity percentage decrease occurred in Africa and the Middle East. In Latin America and North America, ASKs dropped by $-43.3 \%$ and $-35.2 \%$, respectively. ASKs declined by $-42.9 \%$ in Europe and by $39.2 \%$ in the Asia-Pacific region.

Table 10.

Pre- and Post-COVID-19 Impact on Passenger Capacity (ASKs) \% Change by Year.

\begin{tabular}{llll}
\hline Regions & Pre COVID-19 & Post COVID-19 & Impact \\
\hline Global & 5.73 & -40.4 & -34.67 \\
North America & 3.04 & -35.2 & -32.16 \\
Europe & 4.85 & -42.9 & -38.05 \\
Asia-Pacific & 7.36 & -39.2 & -31.84 \\
Middle East & 9.62 & -46.1 & -36.48 \\
Latin America & 5.82 & -43.3 & -37.48 \\
Africa & 4.63 & -50.4 & -45.77 \\
\hline
\end{tabular}

Source: Data calculated by the researchers (2020)

The information presented in Table 10 shows that the ASKs was critically impacted in all six regions. The average ASKs of the Middle East was better in comparison to the rest of the regions. The average ASKs is better in the AsiaPacific region than North America, Latin America, Europe and Africa. It will take the airline industry in all six regions, as well as the global airline industry, many years to recover its ASKs.

\section{Airline Industry Revenues}

All the activities of a business depend on sufficient revenues, and enhancing its revenue is the ultimate goal of any business. In the airline industry, revenue is generated via two main activities: selling of passenger tickets and transporting cargo. 
Table 11.

Airline Industry Revenues by Years.

\begin{tabular}{|c|c|c|c|c|c|c|c|c|c|c|c|c|c|c|c|c|c|}
\hline Years & 2004 & 2005 & 2006 & 2007 & 2008 & 2009 & 2010 & 2011 & 2012 & 2013 & 2014 & 2015 & 2016 & 2017 & 2018 & 2019 & $2020 \mathrm{~F}$ \\
\hline $\begin{array}{l}\text { REVENUES, } \\
\$ \text { billion }\end{array}$ & 379 & 413 & 465 & 510 & 570 & 476 & 564 & 642 & 706 & 720 & 767 & 721 & 709 & 755 & 812 & 838 & 419 \\
\hline $\begin{array}{l}\% \\
\text { change }\end{array}$ & 17.7 & 9.1 & 12.6 & 9.6 & 11.7 & -17 & 18.4 & 14 & 9.8 & 2.1 & 6.5 & -6.1 & -1.6 & 6.5 & 7.6 & 3.2 & -50 \\
\hline $\begin{array}{l}\text { Passenger, \$ } \\
\text { billion }\end{array}$ & 294 & 323 & 365 & 399 & 444 & 374 & 445 & 509 & 528 & 537 & 538 & 545 & 545 & 584 & 610 & 612 & 241 \\
\hline $\begin{array}{l}\text { Cargo, \$ } \\
\text { billion }\end{array}$ & 66.7 & 68.6 & 76.2 & 84.1 & 87.9 & 70.6 & 88.6 & 96.1 & 95.1 & 92.1 & 92.9 & 83.8 & 80.8 & 95.9 & 111 & 102 & 110.8 \\
\hline
\end{tabular}

Source: (iata.org Industry Statistics)

The data presented in Table 11 shows that revenue increased in the airline industry from 2004 to 2008 . However, it decreased in 2009 due to the 2008 financial crisis. A decrease was also recorded in 2015 and 2016 due the MERS coronavirus. However, the airline industry quickly reorganised and recovered the revenue with higher growth in subsequent years (2011 to 2019). This demonstrates the confidence that consumers and other businesses (tourism and hospitality, import and export and international business sectors) have in the industry. Actually, the airline industry encourages those types of revenue streams by improving its facilities, increasing the availability of flights and offering reasonable pricing. However, a sharp decline in revenue occurred in due to the COVID-19 pandemic (50\% decrease) While COVID-19 affected revenue from passenger tickets, it had no effect on the revenue from transporting cargo.

Table 12.

Pre- and Post-COVID-19 Impact on Industry Revenue.

\begin{tabular}{llll}
\hline & Pre COVID-19 & Post COVID-19 & Impact \\
\hline Revenues, \$ billion & 627.9375 & 419 & 8.9375 \\
\% change & 6.5375 & -50 & -43.4625 \\
Passenger, \$ billion & 478.25 & 241 & 237.25 \\
Cargo, \$ billion & 87.06875 & 110.8 & 23.73125 \\
\hline
\end{tabular}

Source: Data calculated by the researchers (2020)

As seen in the results shown in Table 12, COVID-19 has had a significant impact on revenue in the airline industry. The average revenue decreased up to $\$ 208.9375$ billion with an average impact of $-43.4625 \%$. The passenger

Table 13.

Key Factors in the Airline Industry.

\begin{tabular}{|c|c|c|c|c|c|c|c|c|}
\hline Key Factors & 2013 & 2014 & 2015 & 2016 & 2017 & 2018 & 2019 & $2020 \mathrm{~F}$ \\
\hline Aircraft Fleet & 25,150 & 25,926 & 26,608 & 27,585 & 28,340 & 29,507 & 29,697 & 20,261 \\
\hline $\begin{array}{l}\text { Value of trade carried, } \\
\text { \$billion }\end{array}$ & 6,413 & 6,468 & 5,616 & 5,459 & 6,052 & 6,754 & 6,504 & 5,543 \\
\hline $\begin{array}{l}\text { Value of tourism spend, } \\
\text { \$billion }\end{array}$ & 623 & 660 & 665 & 651 & 764 & 843 & 902 & 457 \\
\hline Tax Contribution, \$billion & 107 & 111 & 113 & 117 & 122 & 125 & 129 & 136 \\
\hline Fuel spend, \$billion & 228 & 226 & 175 & 133 & 149 & 180 & 188 & 78 \\
\hline Labor costs, $\$$ billion & 135 & 142 & 150 & 160 & 171 & 174 & 187 & 103 \\
\hline Labor in Million & 2.35 & 2.42 & 2.55 & 2.65 & 2.79 & 2.79 & 2.9 & 1.87 \\
\hline $\begin{array}{l}\text { Consumers spend on air } \\
\text { transport in \$billion }\end{array}$ & 752 & 769 & 752 & 737 & 787 & 845 & 876 & 434 \\
\hline
\end{tabular}

revenue average decreased to $\$ 237.25$ billion. In contrast, the cargo revenue increase was $\$ 23.73125$ billion. Thus, COVID-19 had no impact on the industry's cargo revenue. 
Productive investment is essential for a business and its survival; a company's future is linked to it. According to the IATA 2019 end-year report page no. 3, "next year commercial airlines are scheduled to take delivery of over 2,206 new aircraft, an investment of around $\$ 123$ billion by the industry, as the Boeing 737 MAX returns to service in 2020. The improvement in returns (ROIC) gave the industry confidence to invest on this scale in some regions". In contrast, due to COVID-19, business conditions are becoming less favourable and more problematic. Remarkable growth in the size of the aircraft fleet has occurred since 2013, but a sharp decline occurred in 2020. The airline industry reduced its investment in its fleet; there was a $-31.77 \%$ change in comparison to the previous year. It is also worth mentioning that the industry supports international trade and there is continuous growth in the value of trade carried by the industry every year except for 2015 and 2016 (decline due to MERS). Another downturn was seen due to COVID-19.

The airline industry also supports the hospitality sector. A significant effect was seen in the number of tourists that were travelling. While it was forecasted to be $\$ 968$ billion in 2020 , COVID-19 had a negative impact on the tourist and hospitality sectors. The airline industry is generating sufficient revenue for governments via its tax contribution. That trend has been increasing since the 2013. It is expected that this industry will generate $\$ 136$ billion in tax revenue for governments.

Table 14.

Pre-and Post-COVID-2019 Impact on Key Factors in the Industry.

\begin{tabular}{llll}
\hline Key Factors & Pre COVID-19 & Post COVID-19 & Impact \\
\hline Aircraft Fleet & 27,545 & 20,261 & 7,284 \\
Value of trade carried, \$billion & 6,181 & 5,543 & 638 \\
Value of tourism spend, \$billion & 730 & 457 & 273 \\
Tax Contribution, \$billion & 118 & 0 & $\$ 123 \mathrm{bn}$ \\
Fuel spend, \$billion & 183 & 78 & 105 \\
Labor costs, \$ billion & 160 & 103 & 57 \\
Labor in Million & 3 & 1.87 & 1.13 \\
Consumers spend on air transport in \$billion & 788 & 434 & 354 \\
\hline
\end{tabular}

Source: Data calculated by the researchers 2020.

The average results of the key factors pre- and post-COVID-19 show that all the factors were negatively impacted by COVID-19. Airline industry employees were affected the most. The workforce decreased by almost 1.13 million employees, worldwide, which is very significant. Moreover, the value of trade carried by the industry was also negatively impacted by COVID-19. Tourism activities were also significantly affected by COVID-19, experiencing a $\$ 273$ billion decrease due to the pandemic. On average, $\$ 118$ billion in tax revenue contributions to governments was affected by COVID-19. Ultimately, the industry needs help from respective country's government. Consequently, the industry received $\$ 123$ billion in aid from respective country's government. A revenue generating industry became a troubled industry. The current and future health of the industry is uncertain. If the COVID-19 pandemic continues, the entire industry will become paralyzed, and some airlines will go bankrupt. Revival of the airline industry is linked with reopening a country's borders, easing lockdowns, implementing tax holidays for a number of years, subsidising fuel costs, etc.

\section{Conclusion and Recommendations}

The airline industry has become essential for trade and for the hospitality and tourism sectors, all of which are crucial for the survival of the economy. The current condition of the airline industry is not favourable for investors, governments, management, suppliers, workers, aviation companies and tourists. The COVID19 pandemic has decreased consumer confidence in the airline industry. Consumers are very conscious about health issues. The current COVID-19 condition is unpredictable and no country in the world wants to open its borders. The COVID-19 pandemic has affected the world differently; some countries are affected more than others, and some countries have not experienced a significant impact. Countries with large economies have been most affected. 
The accounting information presented in this study showed that the airline industry's performance was good before COVID-19. The industry was enjoying good returns, making a sufficient contribution to the government's tax revenues and offering a significant number of direct and indirect employment opportunities. Its good performance effectively contributed to the world economy. Its good performance promoted trade activities and the hospitality and tourism industry worldwide. The prevailing condition of the airline industry is very poor. It has experienced losses in consumer confidence, invertor trust and workforce morale. Downsizing and reduction in its workforce have created many problems for industry management and government. Due to COVID19 , the airline industry significantly decreased its investment in its aircraft fleet, the numbers of workers, its NP, its tax revenue, the amount of trade it carries, its EBIT, its revenues, and it's ROIC, region-wise and globally.

The future of the industry is unpredictable because it is linked to the COVID-19 pandemic. Every day, COVID-19 reduces confidence in the industry's performance. Some accounting variables, such as NP, will return to their previous levels within two to three years. Operating income and OPM will increase within five years. A return to average NP and NPM will take longer. Revenues will recover quickly in comparison to operating profit and NP. It is expected that operating costs will be enhanced due to taking precautionary measures for flight operations during the COVID-19 pandemic. COVID-19 has not had an adverse effect on cargo revenue. Cargo revenue showed a positive increase throughout the sample period. Because the COVID-19 pandemic is not yet under control, the airline companies is different countries are scaling back their domestic operations. Small domestic operations are going on in different countries around the world. However, that approach is not sufficient for the industry to generate desired revenues, operating profit, NP, tax revenues and employment opportunities. It is recommended that flight operations be resumed with strict mandatory precautionary measures. The airline industry should thoroughly review the pandemic and compile a list of green countries, and then submit a proposal to the government for reopening operations in those countries. However, the significant economic losses experienced by the countries around the world cannot be ignored. Due to globalisation, all countries are interdependent and the airline industry plays a vital role in promoting globalisation.

\section{References}

Aman, Q, \& Altass, S. (2019). Impact of Capital Structure on Business Performance: A case of Emirates Airline. Amazonia Investiga, 8(21), pp. 62-72. Retrieved from https://amazoniainvestiga.info/index.php/amaz onia/article/view/48

Alessandri, P. and Mumtaz, H. (2019). Financial regimes and uncertainty shocks. Journal of Monetary Economics, 101, pp. 3146.

Atkeson, A. (2020). What will be the economic impact of COVID-19 in the US? Rough estimates of disease scenarios (No. w26867). National Bureau of Economic Research. https://www.nber.org/papers/w26867

Barro, R., Ursua, J. and Weng, J. (2020). The coronavirus and the great influenza pandemic: Lessons from the "Spanish flu" for the coronavirus's potential effects on mortality and economic activity (No. w26866). National Bureau of Economic Research.

Basu, S. and Bundick, B. (2017). Uncertainty shocks in a model of effective demand. Econometrica. 85 (3), 937-958.

Bloom, N. (2014). Fluctuations in uncertainty. Journal of Economic Perspectives, 28 (2), 153176. https://doi. org/10.1257/jep.28.2.153.

Caggiano, G., Castelnuovo, E. and Groshenny, N. (2014). Uncertainty shocks and unemployment dynamics in US recessions. Journal of Monetary Economics, 67, pp. 78-92. Caggiano, G., Castelnuovo, E. and Pellegrino, G. (2017). Estimating the real effects of uncertainty shocks at the zero-lower bound. European Economic Review, 100, pp. 257-272. Davies, R.E.G. (2016). Airlines of the jet age: A history. Smithsonian Institution.

Eichenbaum, M., Rebelo, S. and Trabandt, M. (2020). The macroeconomics of epidemics (No. w26882). National Bureau of Economic Research.

Franke, M. and John, F. (2011). What comes next after recession? Airline industry scenarios and potential end games. Journal of Air Transport Management, 17 (1), 19-26.

Gilbertson, D. (2020). US airlines must continue flying if they accept coronavirus relief. USA Today. [Online]. 31 March. [Accessed 5th May 2020]. Available from: https://www.usatoday.com/story/travel/airlinenews/2020/03/31/coronavirusstimulus-

package-us-airlines-must-continue-

flying/5093641002/

Goodman, C.J. (2008). Take-off and descend of airline employment. Monthly Labor Review. 131, p. 3.

Hayes, A (2020), Transport Sector. Investopedia. [online] (Accessed 25th August 


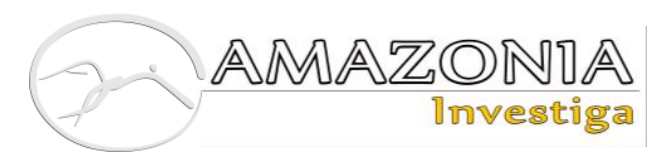

2020) Available from: https://www.investopedia.com/terms/t/transpor tation_sector.asp\#: :text=The\%20transportatio n\%20sector\%20is\%20an,those \%20that \%20pro vide\%20transportation\%20infrastructure (Accessed 25th August, 2020)

International Airline Transport Association, IATA (2020). Industry Economic Performance [online] (Accessed 22nd August 2020). Available from: https://www.iata.org/en/publications/economic s/ (Accessed 22nd August 2020)

Legchilina, E. (2020). The impact of changes in labor relations on mortality rates in Russia. Amazonia Investiga, 9(26), 3651. https://doi.org/10.34069/AI/2020.26.02.4 Ludvigson, S.C., Ma, S. and Ng, S. (2015). Uncertainty and business cycles: Exogenous impulse or endogenous response? (No. w21803). National Bureau of Economic Research.

Mahutga, M.C., Ma, X., Smith, D.A. and Timberlake, M. (2010). Economic globalization and the structure of the world city system: the case of airline passenger data. Urban Studies, 47 (9), pp.1925-1947.

Master of Public Health. MPH (2020) Outbreak: 10 of the worst pandemics in history [online] (Accessed 11TH August 2020). Available from: https://www.mphonline.org/worst-pandemicsin-history/

Mazareanu, E (2020) Airline Passenger Traffic [online] (Accessed 18th August 2020) Available

from:https://www.statista.com/statistics/56471 7/airline-industry-passenger-traffic-globally/

McKibbin, W. and Fernando, R. (2020). The global macroeconomic impacts of COVID-19: Seven scenarios. The Brookings Institution Report. Available from: https://www.brookings.edu/research/theglobal-macroeconomic-impacts-of-covid-19seven-scenarios/.(Retrieved on August 22nd 2020)

Pearce, B. (2012). The state of air transport markets and the airline industry after the great recession. Journal of Air Transport Management, 21, pp. 3-9.

Sehl, K (2020) How the Airline Industry Survived SARS, 9/11, the Global Recession and More [online] (Accessed 12th August 2020). Available from: https://apex.aero/2020/06/10/aftershockscoronavirus-impact/

Sibdari, S., Mohammadian, I. and Pyke, D.F. (2018). On the impact of jet fuel cost on airlines' capacity choice: evidence from the US domestic markets. Transportation Research Part E, 111, pp. 1-17.

Sobieralski, J, B. (2020). COVID-19 and airline employment: Insights from historical uncertainty shocks to the industry. Transportation Research Interdisciplinary Perspective. 5, 100123.

Tan, K.M. (2016). Incumbent response to entry by low-cost carriers in the US airline industry. Southern Economic Journal, 82 (3), pp. 874892.

Von Nordenflycht, A. and Gittell, J.H. (2013). Context, process, and outcomes of collective bargaining in the US airline industry. In: Stanger, H.R., Frost, A.C., Clark, P.F. eds. Collective bargaining under duress: Case studies of major US industries, pp. 9-43.

Wolfers, J. (2020). The unemployment rate is probably around 13 percent. New York Times. [Online] 3 April. [Accessed 5 May 2020]. Available from: https://www.nytimes.com/2020/04/03/upshot/c oronavirus-job-less-rate-great-depression.html 